\title{
Transliteration from an Image Using Smartphone
}

\author{
Suraj Palwe ${ }^{1}$, Deepak Khadke ${ }^{2}$, Chandrakant Mundane ${ }^{3}$, Akash Pande ${ }^{4}$, \\ Vaibhav Jadhav ${ }^{5}$, Prof. Rajesh A. Patil ${ }^{6}$
}

\begin{abstract}
Nowadays, almost everybody is capable of clicking digital pictures using their smartphones. Social media has provided them a platform to share them with outside world. Some images contain text written in scripts which seems foreign to others. There has been a lot of work done on extracting that text from that image. We in this paper have proposed a method to bring that a little bit forward. We intend to build the real time text extraction using Google's Tesseract open source OCR engine as well as the script conversion from the clicked image instantly. Performance is evaluated on the basis of a specially designed android application.
\end{abstract}

Keywords: Tesseract, OCR, Transcription, Script Conversion, Transliteration

\section{Introduction}

This project aims at making a Mobile Application which recognizes the text from an image captured from a mobile camera and gives information related to it. Extracting text from natural scene and displaying information related to it will help to know the surrounding environment. So the app basically recognizes text from an image on real time basis and further converts it into a user friendly script. It is an android application which uses internet to transliterate the text. Hence with using just smartphone, user can recognize texts of scripts, although unknown to him. This application will help tourists who do not know local languages of particular country/area. He /she will get information with the help of this application. This application will also help to know the information related to any hand-held objects. As we will embed this application in a smart phone, there will be more mobility.

There has been great work done on extracting text from a clear background. But very little work has been done on extracting text against general or colored background. In this area, methods like Haar transform [4], Sliding window, Gaussian pyramid, SVM or Service Vector Machine [5] have been developed to extract and recognize text from an image. This all work is related to image processing. These algorithms use basic features of image like intensity, edges, pixel density, localization of group of pixels. The color clustering algorithm identifies text in more sophisticated way. It first converts the image into grayscale and then binarizes it. Then it applies horizontal and vertical heuristics to identify the transitions of $\operatorname{black}(0)$ and white(1). Here, text areas will be having large number of such transitions. In this way, it identifies potential text regions from the image. There is a little work done in field of real time recognition of script. There are some online professional tools like Quillpad, which takes text as input and convert it into Other Indian regional scripts. But, such tools preferentially require internet connection and also they are costly.

\section{System Design}

\section{A. Tesseract Library}

- It is an open source OCR (Optical Character Recognition) engine and library developed by Google. We are using it to extract the text from image.
- So, in first step, Tesseract basically gives us the text which then we can transliterate into 20 Indian regional languages.

- Recognition proceeds as a two pass process[1]:-

1) In the first pass an attempt is made to recognize each word in turn. Each word that is satisfactory is then sent to adaptive classifier as training data.

2) Second pass is run over the page, in which words that were not recognized well enough are recognized again.

- Line finding: It involves line detection which uses histogram stretching.

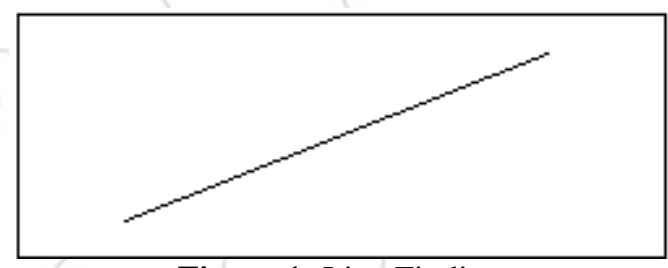

Figure 1: Line Finding

- Baseline fitting: The baselines are fitted by partitioning the blobs into groups.

- Fixed Pitch Detection, Chopping and proportional word finding: It detects whether it has fixed pitch detection, chops accordingly and then the character/word is sent to recognize.
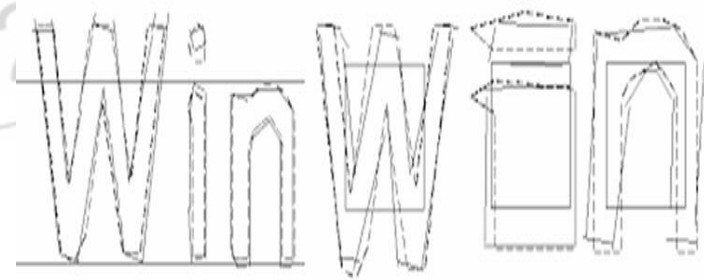

Figure 2: Baseline Fitting [1]

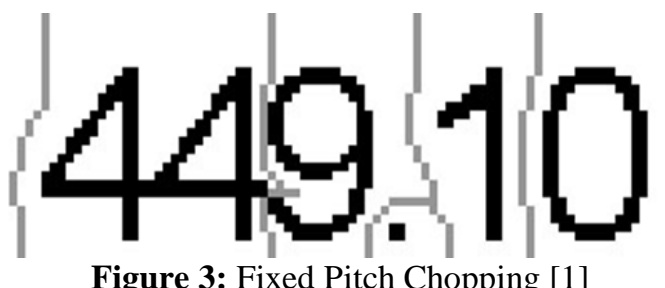

Figure 3: Fixed Pitch Chopping [1]

- Use of extracted text to convert into different scripts:

Dictionary of words is been created for 20 Indian regional languages.

For e.g. : $\mathrm{K}$ as के in Marathi language. 


\section{International Journal of Science and Research (IJSR) \\ ISSN (Online): 2319-7064}

Index Copernicus Value (2013): 6.14 | Impact Factor (2015): 6.391

- So this process is followed for each word and the complete sentence is derived.

- Drawbacks: Now consider the word D which can be pronounced as S as well as द. This is explained as an example in Marathi, but follows same for other languages.

- How to overcome this drawback: Dictionary of words is needed to be created using the previous results and storing them.

\begin{tabular}{|c|c|c|c|c|}
\hline $\begin{array}{l}\text { क } \\
\text { Kabir }\end{array}$ & $\begin{array}{l}\text { ख } \\
\text { Khandala }\end{array}$ & $\begin{array}{l}\text { ग } \\
\text { Gagan }\end{array}$ & $\begin{array}{l}\text { घ } \\
\text { Ghajini }\end{array}$ & ङ \\
\hline $\begin{array}{l}\text { च } \\
\text { each }\end{array}$ & $\begin{array}{l}\text { छ } \\
\text { Chhattisgarh }\end{array}$ & $\begin{array}{l}\text { ज } \\
\text { Jamaica }\end{array}$ & $\begin{array}{l}\text { झ } \\
\text { Zapak }\end{array}$ & ग \\
\hline $\begin{array}{l}\text { ट } \\
\text { Turmeric }\end{array}$ & $\begin{array}{l}\text { ठ } \\
\text { Kathmandu }\end{array}$ & $\begin{array}{l}\text { S } \\
\text { Dumb }\end{array}$ & $\begin{array}{l}\text { ढ } \\
\text { Dhaka }\end{array}$ & $\begin{array}{l}\text { ण } \\
\text { Praan }\end{array}$ \\
\hline $\begin{array}{l}\text { त } \\
\text { Tanishq }\end{array}$ & $\begin{array}{l}\text { थ } \\
\text { Thunder }\end{array}$ & $\begin{array}{l}\text { द } \\
\text { The }\end{array}$ & $\begin{array}{l}\text { ध } \\
\text { Dhanush }\end{array}$ & $\begin{array}{l}\text { न } \\
\text { Number }\end{array}$ \\
\hline $\begin{array}{l}\text { प } \\
\text { Purpose }\end{array}$ & $\begin{array}{l}\text { फ } \\
\text { Funda }\end{array}$ & $\begin{array}{l}\text { ब } \\
\text { Button }\end{array}$ & $\begin{array}{l}\text { भ } \\
\text { Bhatinda }\end{array}$ & $\begin{array}{l}\text { म } \\
\text { Merge }\end{array}$ \\
\hline $\begin{array}{l}\text { य } \\
\text { My }\end{array}$ & $\begin{array}{l}\text { T } \\
\text { Ratan }\end{array}$ & $\begin{array}{l}\text { ल } \\
\text { Love }\end{array}$ & $\begin{array}{l}\text { व } \\
\text { Version }\end{array}$ & $\begin{array}{l}\text { श } \\
\text { Shun }\end{array}$ \\
\hline $\begin{array}{l}\text { ष } \\
\text { Shun }\end{array}$ & $\begin{array}{l}\text { स } \\
\text { Certain }\end{array}$ & $\begin{array}{l}\text { ह } \\
\text { Hut }\end{array}$ & $\begin{array}{l}\text { ळ } \\
\text { Kamal }\end{array}$ & $\begin{array}{l}\text { क्ष } \\
\text { Akshay }\end{array}$ \\
\hline $\begin{array}{l}\text { ज } \\
\text { Dnyaneshwar }\end{array}$ & & & & \\
\hline
\end{tabular}

Figure 4: English to Marathi Transliteration

B. Implementation Flowchart:

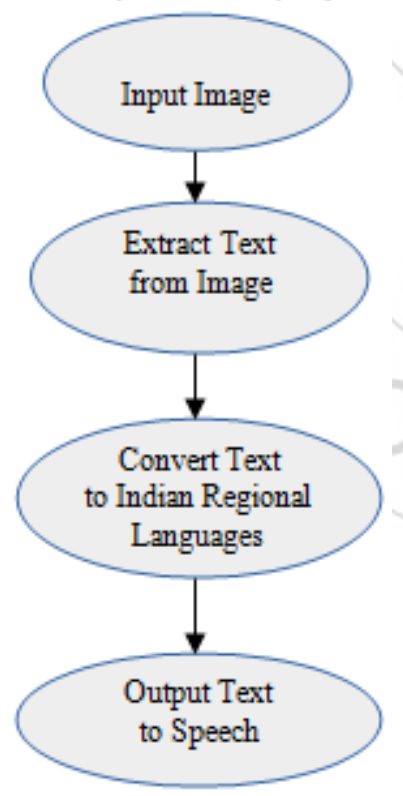

\section{Android Mobile Application:-}

- We have built a mobile application which will let user transcript texts written in scripts unknown to him into scripts known to him.

- The application will first capture the image of the text in camera. Then text will be recognized from it, and subsequently converted into a script in which user wants to see it.
- We are providing audio functionality along with the transcripter. If user is illiterate, the audio facility will help him understand what is written on the board.

\section{Results}

Below are the screenshots of mobile application.
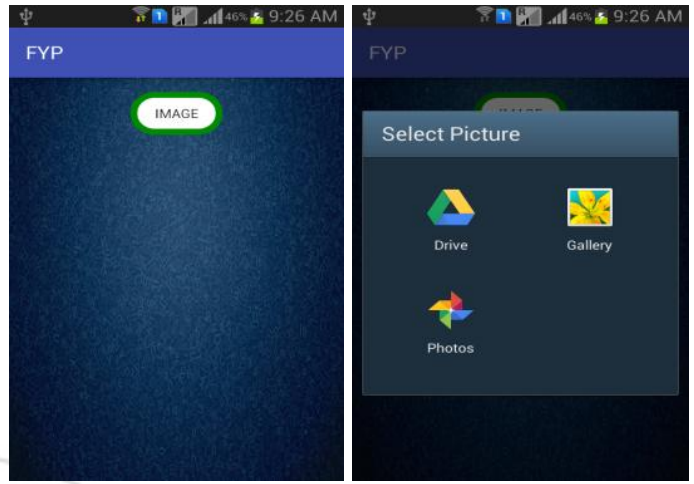

Figure 5: Input image on Figure 6 Select image mobile screen from gallery

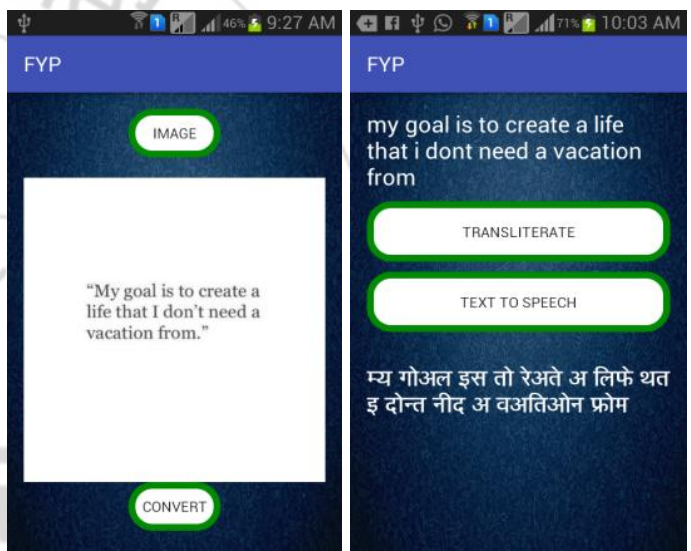

Figure 7: Image display Figure 8Transliteration of text

\section{Conclusion}

So, this application enables user to transliterate the text from an image on real time basis using internet. Currently, there are hardly any applications regarding this field. Neither have they had the access to recognize Indian regional scripts. All other technologies use Roman or Latin script. Our conversion intends to recognize the Indian Regional scripts on which very few work has been done. The application works perfect in given environment, and doesn't need user to be aware of multiple scripts or languages for recognition of foreign texts. Our focus in future would be to transliterate larger amount of text than current conversion which is limited to text written on boards and small platforms.

\section{References}

[1] Ray Smith, An Overview of the Tesseract OCR Engine

[2] Keechul Jung, Kwang In Kim, Anil K. Jain, Text Information Extraction in Images and Video: A Survey.

[3] Sahil Badla, Improving The Efficiency Of Tesseract OCR Engine.

[4] Narasimha Murthy K N, Dr. Y S Kumaraswamy,A Novel Method for Efficient Text Extraction from Real Time 


\section{International Journal of Science and Research (IJSR) \\ ISSN (Online): 2319-7064}

Index Copernicus Value (2013): 6.14 | Impact Factor (2015): 6.391

Images with Diversified Background using Haar Discrete

Wavelet Transform and K-Means Clustering.

[5] Satish Kumar, Sunil Kumar, Dr. S. Gopinath, Text

Extraction From Images

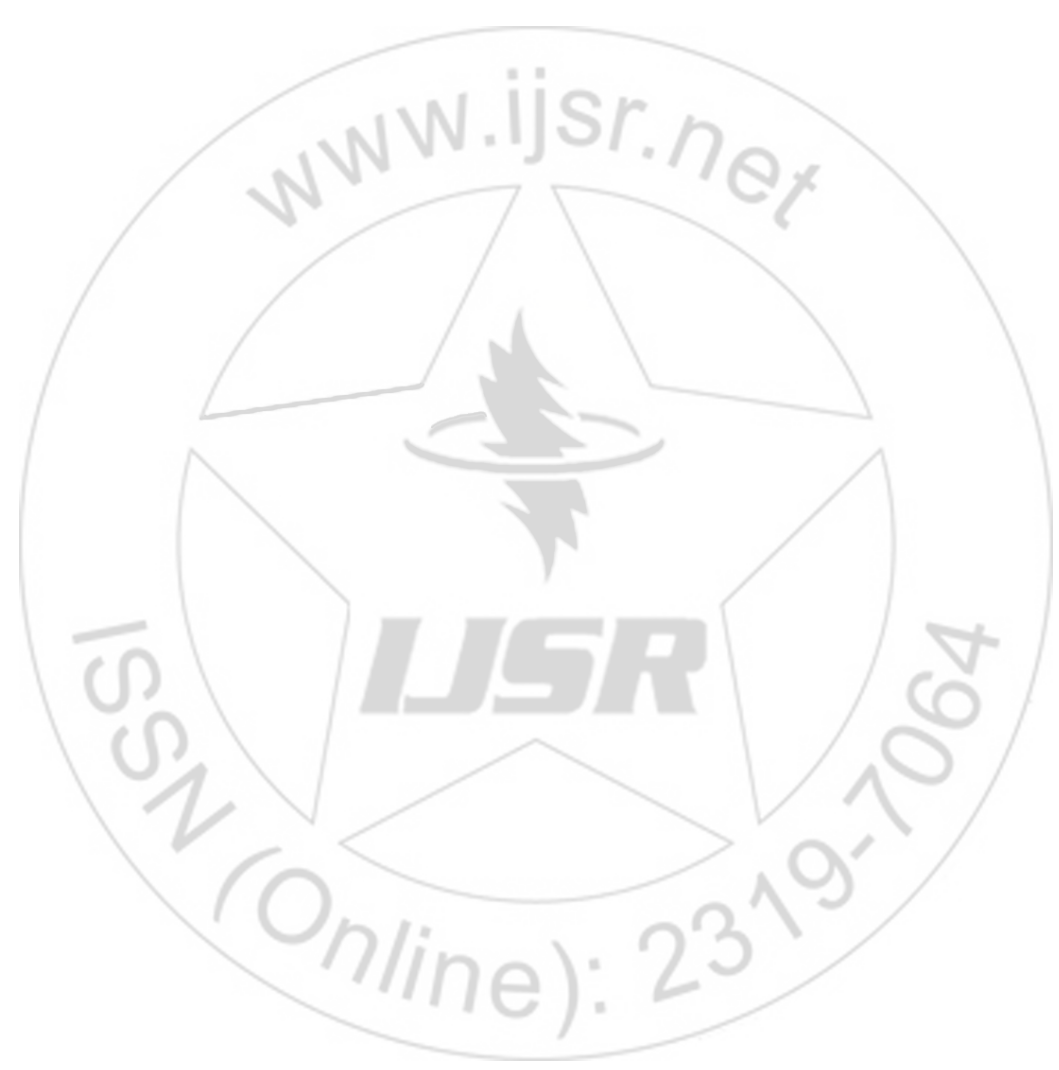

Volume 5 Issue 5, May 2016

www.ijsr.net 